\title{
Energy Information Clearinghouse
}

Final report

Report start date: Sept 30, 2001

Report end date: Sept 30, 2002

Principal Author: Ron Johnson

Date of Issue: October 2003

DOE Award Number: DE-FC26-01N41248 Task 4.1

Submitting organization: University of Alaska Fairbanks Institute of Northern Engineering PO Box 755910, Fairbanks, AK 99775-5910 


\section{DISCLAIMER}

"This report was prepared as an account of work sponsored by an agency of the United States Government. Neither the United States Government nor any agency thereof, nor any of their employees, makes any warranty, express or implied, or assumes any legal liability or responsibility for the accuracy, completeness, or usefulness of any information, apparatus, product, or process disclosed, or represents that its use would not infringe privately owned rights. Reference herein to any specific commercial product, process, or service by trade name, trademark, manufacturer, or otherwise does not necessarily constitute or imply its endorsement, recommendation, or favoring by the United States Government or any agency thereof. The views and opinions of authors expressed herein do not necessarily state or reflect those of the United States Government or any agency thereof." 


\begin{abstract}
Alaska has spent billions of dollars on various energy-related activities over the past several decades, with projects ranging from smaller utilities used to produce heat and power in rural Alaska to huge endeavors relating to exported resources. To help provide information for end users, utilities, decision makers, and the general public, the Institute of Northern Engineering at UAF established an Energy Information Clearinghouse accessible through the worldwide web in 2002. This clearinghouse contains information on energy resources, end use technologies, policies, related environmental issues, emerging technologies, efficiency, storage, demand side management, and developments in Alaska.
\end{abstract}




\section{TABLE OF CONTENTS}

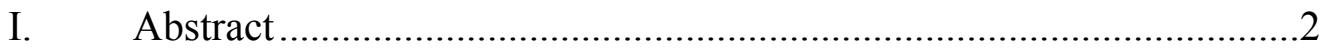

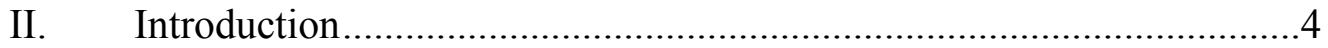

III. Executive Summary ………………………...............................

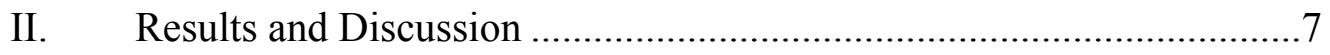

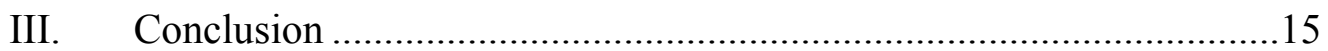

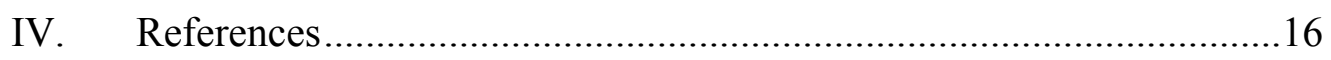




\section{INTRODUCTION:}

Alaska has spent billions of dollars on various energy related activities over the past several decades. Such projects range from smaller utilities used to produce heat and power in rural Alaska to huge projects relating to exported resources. Alaska has vast energy resources with petroleum, coal, and natural gas receiving the most attention to date. But there are also abundant renewable resources, including geothermal, wind, hydropower of various forms (including tidal, waves, and currents), and solar power for up to eight months of the year. With the high cost of heat and power -- especially in rural Alaska -- the state is eager to find ways of reducing state subsidies.

To help provide information for end users, utilities, decision makers, and the general public, the Institute of Northern Engineering at UAF submitted a proposal to AETDL in 2001 to develop an Energy Information Clearinghouse accessible through the worldwide web. This clearinghouse was established in 2002 and contains information on energy resources, end use technologies, policies, related environmental issues, emerging technologies, efficiency, demand side management, and developments in Alaska. This led to the development of a www page discussed below. Efforts to secure funding to maintain this site have not been successful to date.

EXPERIMENTAL: - not applicable for this project 


\section{EXECUTIVE SUMMARY:}

To help provide information for end users, utilities, decision makers, and the general public, the Institute of Northern Engineering at UAF established an Energy Information Clearinghouse accessible through the worldwide web in 2002. This clearinghouse contains information on energy resources, end use technologies, policies, related environmental issues, emerging technologies, efficiency, demand side management, and developments in Alaska.

Energy resources discussed include oil, coal, and natural gas as fossil fuels; geothermal and nuclear power; and renewable resources, including hydropower, wind, wave and tidal, and solar electric as well as solar thermal. Conventional end use technologies discussed are steam, combustion, and hydraulic and wind turbines plus diesel electric generators for the production of electric power; and furnaces and boilers for the production of heat. Steam turbine plants generally have a history of achieving up to $95 \%$ availability and can operate for more than a year between shutdowns for maintenance and inspections. Their unplanned or forced outage rates are typically less than $2 \%$ or less than one week per year. This technology leads the others in total production of electric power in the US. Emerging technologies include fuel cells and thermoelectric generators. Energy storage via electrochemical batteries, flywheels, and hydrogen is also addressed.

Under environmental impacts, we address disposal of spent nuclear fuel, greenhouse gases, $\mathrm{CO}$ emissions in Alaska, fuel spills, and impacts of renewable technologies. As an example of a contentious national and global issue, the US DOE spent 14 years and $\$ 4.5$ billion on studies before recommending in January of 2002 that Yucca Mountain, a barren volcanic structure about 90 miles from Las Vegas, be used to bury thousands of tons of highly radioactive nuclear waste from power plants and nuclear weapons factories. The project faces substantial technical, legal and political challenges, and could be derailed by either house of Congress, the courts or engineering problems. In Alaska, the major ambient air quality issue associated with our use of fossil fuel resources is excessive levels of ambient $\mathrm{CO}$ in urban areas during the winter. This places Anchorage and Fairbanks in jeopardy of being sanctioned by the US EPA. Indoors, Alaska has the highest age-adjusted death rate from accidental $\mathrm{CO}$ poising in the nation.

"Energy conservation" refers to a variety of strategies employed to reduce the demand for energy. This can include adding extra insulation on building exteriors, setting building thermostats closer to ambient temperatures, or carpooling. Conservation is a different practice than increasing energy efficiency, which refers to increasing the useful output for a given energy input. This could involve replacing incandescent light bulbs with compact fluorescent ones, driving more fuel-efficient motor vehicles, and buying more efficient appliances.

With transportation accounting for roughly 25 percent of our nation's energy consumption, a key ingredient for future savings in energy is improving the corporate average fuel economy (CAFÉ) for motor vehicles. Other important components are use of more efficient lighting by homes and businesses, the use of more efficient electric 
motors by industry, and increased use of solar energy for space and water heating. In Alaska, there is a large potential for fuel oil savings in villages by using heat captured from the jacket water of diesel - electric generators for space heating.

Alaska's electrical energy infrastructure differs from that of the rest of the United States in that most consumers in the Lower 48 states are linked to a huge, transcontinental electrical energy grid through transmission and distribution lines. In Alaska, there are at least 175 rural communities in the state that are not interconnected and must rely on their own power sources. These communities rely almost exclusively on diesel electric generators. In the central part of the state, from Fairbanks to the Kenai Peninsula south of Anchorage, (an area called the Railbelt), there is an interconnected grid. Natural gas is the primary fuel used in south central Alaska. Barrow, in far northern Alaska, also relies on natural gas. The largest hydroelectric plant is the state-owned $90 \mathrm{MW}$ Bradley Lake Hydroelectric Project, near Homer, which provides approximately 10 percent of the electrical energy needs of the Railbelt. The Alaska Rural Electric Cooperative Association (ARECA) is the trade association for most electric utilities in Alaska. It provides advocacy and program services to help member utilities in their efforts to serve consumers with affordable, reliable electricity and improve the quality of life in Alaska's communities. 


\section{RESULTS AND DISCUSSION:}

The opening page narrative plus a picture from the homepage appears below. This site is accessible over the www at http://www.uaf.edu/energyin/webpage/opening page.htm.

\section{Energy Information Clearinghouse University of Alaska Fairbanks}

A guide to issues associated with the production of heat and electric power with an emphasis on northern applications. Additional information on energy conservation, environmental issues and energy storage.

Technologies for producing heat and electric power are central to modern civilization and are essential for well-being during much of the year in Alaska and other northern communities. Today, those most widely deployed in Alaska for electric power production include gas and steam turbines in urban areas, diesel-electric generators in rural regions, and hydropower in both rural and urban regions. The first three utilize fossil fuels while the latter together with wind and solar are examples of technologies based on renewable resources. Nuclear power, although widely used worldwide, is not currently utilized in Alaska.

Heating is typically accomplished using furnaces and boilers fueled with oil or natural gas or wood stoves. But dwellings and commercial buildings may also be heated

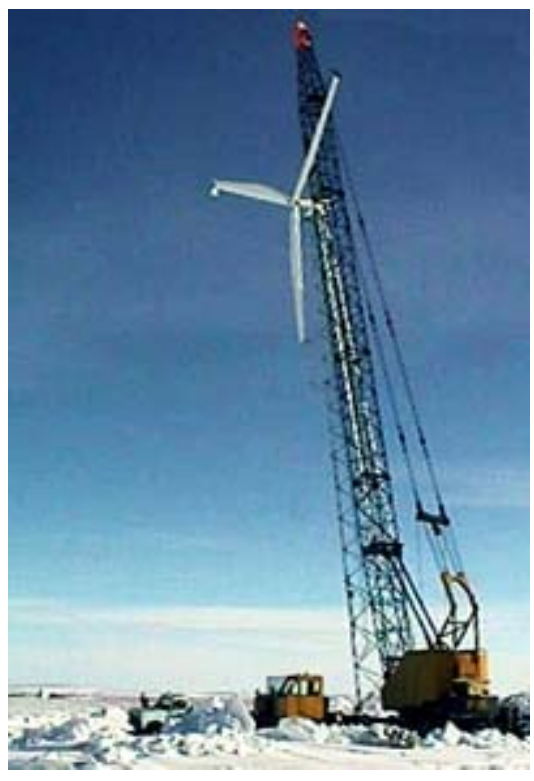

Erection of wind turbine at Kotzebue Electric Association. by operating the electric power generators in a cogeneration mode.

Energy storage is a critical issue for renewablebased technologies. The storage mechanism is elevated water in the case of hydropower while electrochemical batteries are commonly used to store electricity directly.

Other important issues include energy conservation, environmental impacts, resources, end uses, demand side management and efficiencies.

Examples of emerging technologies worth mentioning include fuel cells, thermoelectric generators, flywheels, and energy storage using hydrogen. These technologies are not now in widespread use.

The University of Alaska as well as various utilities and State and Federal agencies are currently pursuing energy related activities in Alaska. 
As an example of one of the inside pages accessed from the opening page, see the below.

\section{STEAM AND GAS TURBINE POWER PLANTS}

Fossil-fuel fired central station power plants world-wide normally use either steam or gas turbines to provide mechanical power to electrical generators. Pressurized high temperature steam or gas expands through various stages of a turbine, transferring energy to the rotating turbine blades. The turbine is mechanically coupled to a generator that produces electricity. Steam turbine power plants operate on a Rankine cycle, where the steam is created externally to the turbine in a boiler, where water under pressure passes through a series of tubes until it boils, eventually becoming superheated steam. The heat is provided by a furnace, normally burning coal, natural gas, or fuel oil. However, the heat could also be provided by biomass or solar or nuclear energy. Then, the plants wouldn't be fossil-fuel fired. After the steam exits the turbine, it is condensed in a condenser, pumped to boiler pressure, and reintroduced into the boiler. Heat is normally rejected from the condenser to a body of water such as a river.

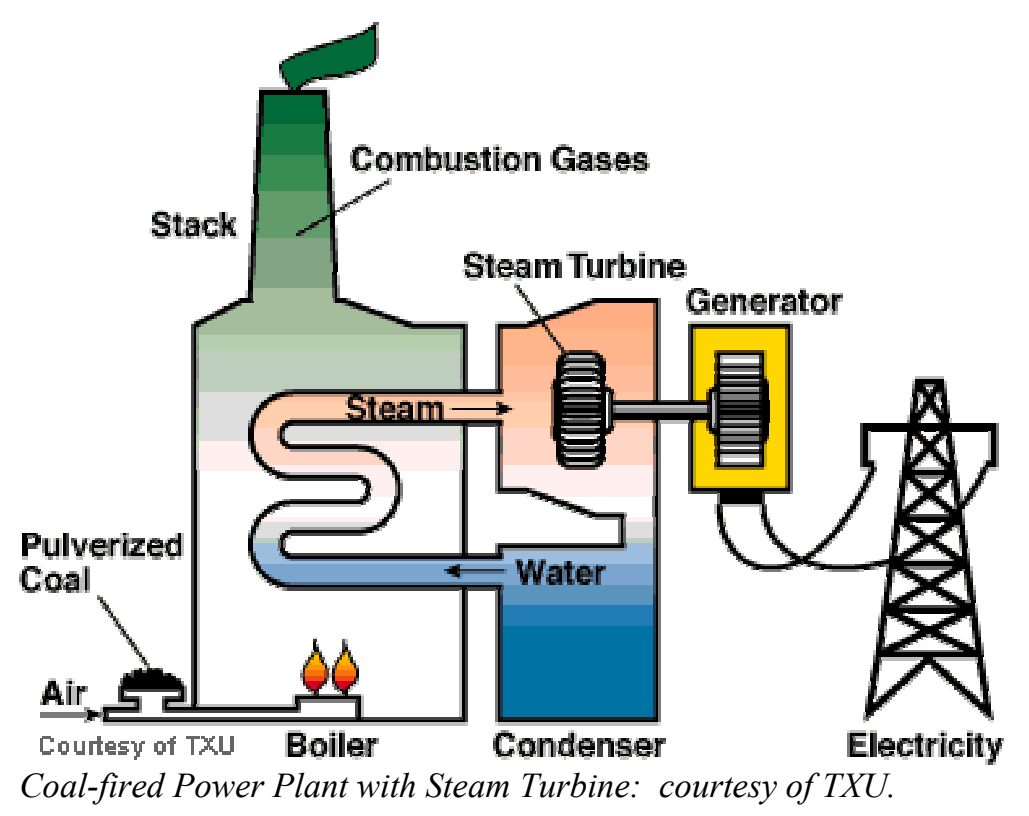

A gas turbine plant uses a compressor to compress the inlet air upstream of a combustion chamber. Then, the fuel (normally natural gas) is introduced and ignited to produce high temperature combustion products (mostly nitrogen and uncombusted oxygen) which enter the turbine. The turbine powers the generator plus the compressor. The cycle efficiency can be increased by installing a recuperator after the turbine exhaust to preheat the inlet air after compression. 


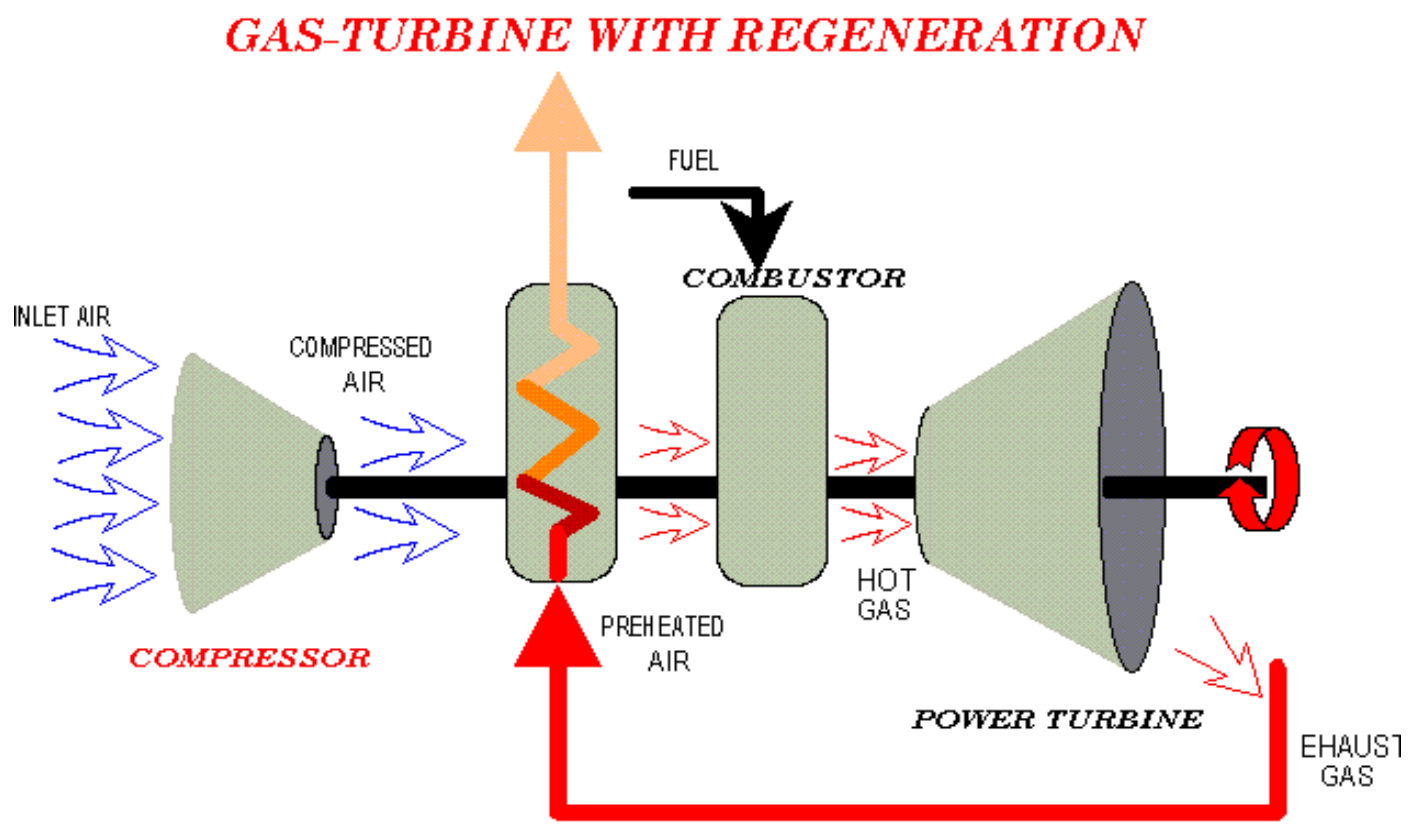

Gas Turbine with Recuperation. Image by www.nyethermodynamics.com.

About $50 \%$ of Alaska's installed capacity is combustion turbines and $13 \%$ steam turbines with $60 \%$ of the electricity produced using natural gas. Worldwide, $40 \%$ of the electricity is produced from coal-fired steam turbines and $13 \%$ from natural gas.

Modern large condensing steam turbine plants have efficiencies approaching 40-45\%, with boiler/steam turbine installation costs between $\$ 800-\$ 1000 / \mathrm{kW}$ or greater, depending on environmental requirements. The steam turbine itself is generally considered to have an availability at least $99 \%$, with longer than a year between shutdowns for maintenance and inspections.

Gas turbine development accelerated in the 1930's as a means of propulsion for jet aircraft. It was not until the early 1980's that the efficiency and reliability of gas turbines had progressed sufficiently to be widely adopted for stationary power applications. Gas turbines range in size from $30 \mathrm{~kW}$ (microturbines) to $250 \mathrm{MW}$ (industrial frames). Industrial gas turbines have efficiencies approaching $40 \%$ and $60 \%$ for simple and combined cycles respectively.

The gas turbine share of the power generation market has climbed from $20 \%$ to $40 \%$ of capacity additions over the past twenty years, with this technology seeing increased use for baseload power. Much of this growth can be accredited to large ( $>50 \mathrm{MW})$ combined cycle plants that exhibit low capital cost (less than $\$ 550 / \mathrm{kW}$ ) and high thermal efficiency.

The capital cost of a gas turbine power plant can vary between $\$ 300-\$ 900 / \mathrm{kW}$, with the lower end applying to large industrial frame turbines in combined cycle. Availability when fueled with natural gas is in excess of 95\%. In Canada, there have been 28 natural gas-fired combined cycle and cogeneration plants with an average efficiency of $48 \%$. The average power output was $236 \mathrm{MW}$ and installed cost was around $\$ 500 / \mathrm{kW}$. 
Pruden, D., 2001, Hydrogen system efficiency targets, pp 87 - 91 IN: McLean, G. (ed.), Proceedings of the $11^{\text {th }}$ Canadian Hydrogen Conference, Victoria, B. C.

Review of Combined Heat and Power Technologies, 1999, ONSITE SYCOM Energy Corporation for the California Energy Commission under grant number 98R020974 with the U.S. Department of Energy, Office of Energy Efficiency and Renewable Energy.

Links on this page are:

\section{Steam and Gas Links}

Turbomotor Works

Dresser-Rand

How it Works: Small Gas

Turbine Engine

How Gas Turbines Work

And clicking on the second link leads to http://www.dresser-rand.com/steam/default.asp

One more section is presented below.

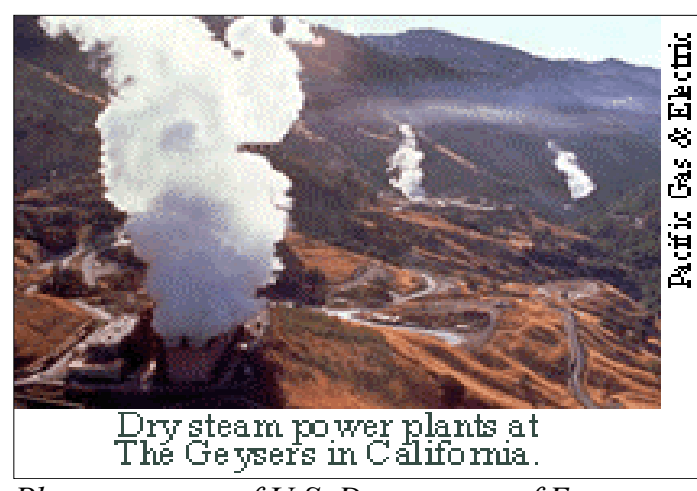

Photo courtesy of U.S. Department of Energy Geothermal Energy Program.

(http://www.eren.doe.gov/geothermal/geobasics.ht $\underline{m l)}$

How is geothermal energy a resource? http://www.iclei.org/efacts/geotherm.htm http://solstice.crest.org/renewables/geothermal/grc/supply.html http://www.eren.doe.gov/geothermal/geobasics.html

What are the methods of harvesting this resource and how is it used? http://www.iclei.org/efacts/geotherm.htm http://solstice.crest.org/renewables/geothermal/grc/supply.html http://www.eren.doe.gov/geothermal/geobasics.html

\section{Geothermal Energy}

What is geothermal energy?

Geo, meaning (earth) and thermal meaning heat) is a naturally occurring energy in the form of heat under the surface of the earth. This energy source can be only a few feet below the surface, in water that comes to the surface of the ground, in hot rocks miles below the surface, or even further down in molten rock called magma. This energy originates from radioactive decay deep within the earth's crust. The following websites give detailed information of geothermal energy. 
What is the potential for this resource?

http://www.iclei.org/efacts/geotherm.htm

http://solstice.crest.org/renewables/geothermal/grc/supply.html

http://www.eren.doe.gov/geothermal/geobasics.html

How does geothermal energy compare to other energy resources?

What is the electrical capacity of a geothermal power plant and how does this compare to other sources of energy? "The Geysers", near San Francisco, having a generating capacity of $1360 \mathrm{MW}_{\mathrm{e}}$ is the largest geothermal electric plant in the U.S. It is one of only two locations in the world where a high-temperature, dry steam is found that can be directly used to turn turbines and generate electricity (the other being Larderello, Italy). The Geysers is comparable to the hydroelectric Hoover dam project, which has a generating capacity of $1,345 \mathrm{MW}_{\mathrm{e}}$. Nuclear and coal-fired power plants may have generating capacities on the order of $1000 \mathrm{MW}_{\mathrm{e}}$

\section{http://www.energy.ca.gov/geothermal/}

California's geothermal power plants produce about 40 percent of the world's geothermally generated electricity. U.S. geothermal power plants have a total generating capacity of 2,700 megawatts and produce electricity at $5 \notin$ to $7.5 \notin$ per kilowatt-hour. Iceland gets about one-third of its total energy from geothermal resources. (Ristinen, $\mathrm{R}$ and J. Kraushaar, 1999, Energy and the Environment).

\section{http://www.nrel.gov/documents/geothermal energy.html}

What is the net positive environmental impact as compared to other energy sources? Geothermal power plants have sulfur-emissions rates that average only a few percent of those from fossil-fuel alternatives. The newest generation of geothermal power plants emits only $0.3 \mathrm{lb}$ of carbon (as $\mathrm{CO}_{2}$ ) per MW-hr of electricity generated. This is 1000 times lower than that for a plant using natural gas (methane) and even more for a coalfired plant. Nitrogen oxide emissions are much lower in geothermal power plants than in fossil power plants. Nitrogen-oxides combine with hydrocarbon vapors in the atmosphere to produce ground-level ozone, a gas that causes adverse health effects and crop losses as well as smog.

See - http://solstice.crest.org/renewables/geothermal/grc/what-is.html

What are some negative effects on the environment? Only hot water and natural steam reservoirs are being used today to create large amounts of electricity. Many of the hot water reservoirs, particularly those of higher temperature and salinity, pose the potential for contamination of the soil by salination if the extracted water is not reinjected into the ground. There is also the risk of aquifer disruption when large amounts of water are extracted from the ground. Gaseous air pollutants such as hydrogen sulfide can be liberated into the atmosphere by some hot water reservoirs and by natural steam. But again, this is often less than that emitted by other energy sources. Other possible environmental effects include induced seismic activity if water is injected into dry rock formations or if explosive fracturing techniques are used in normally impermeable rock formations (Ristinen, R and J. Kraushaar, 1999, Energy and the Environment). 


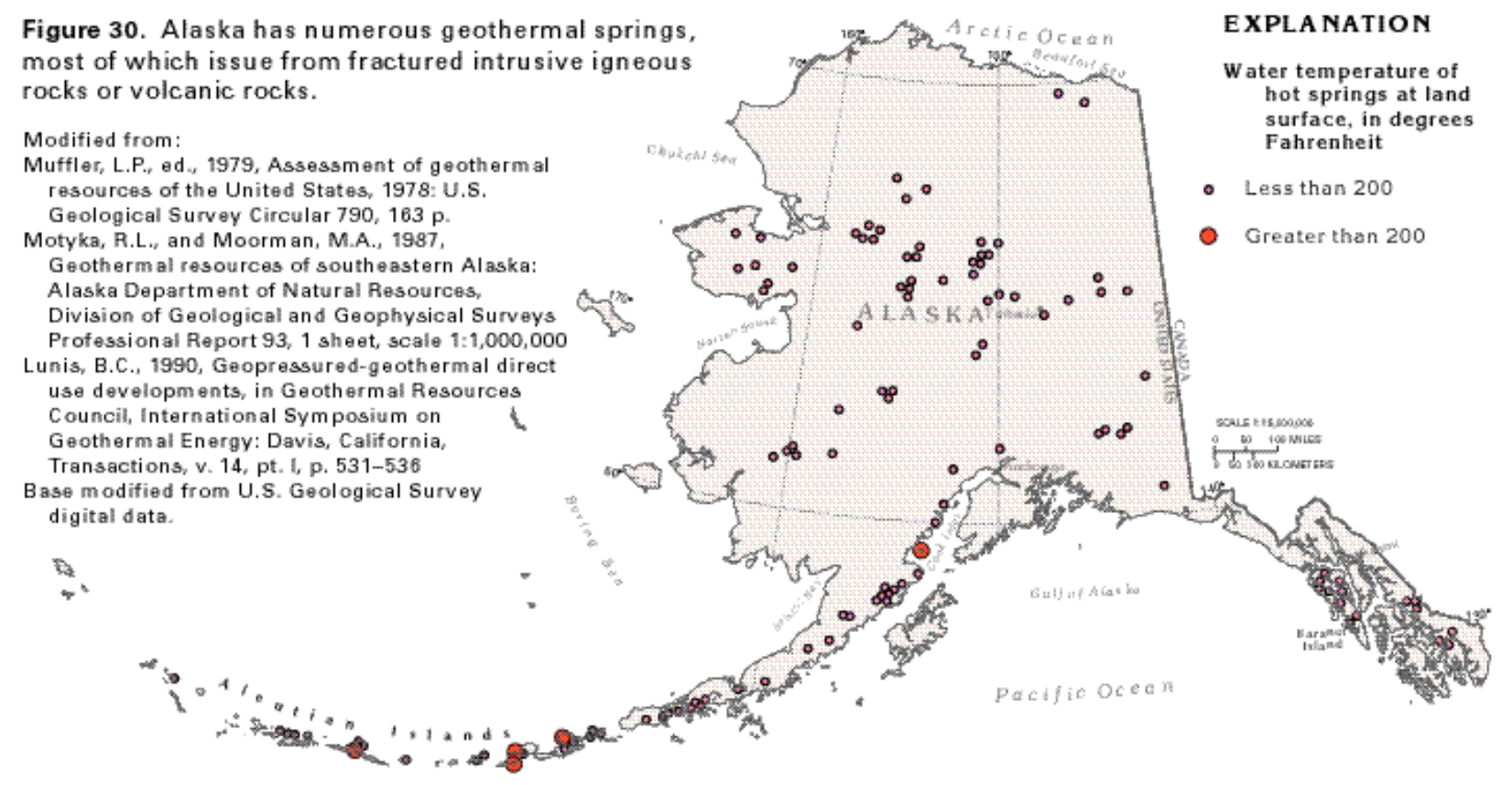

(Photo courtesy of U.S.G.S. <http://capp.water.usgs.gov/gwa/ch n/N-AKtext4.html >)

What is the potential for this energy source in Alaska?

There are many geothermal sources in Alaska but only a few are available for producing good quality steam for direct use with a turbine, for producing electricity, and those that are available generally are not always in the place they are most needed. For use of steam directly from the source it is preferable the steam be well over $200^{\circ} \mathrm{C}$, those at $200^{\circ} \mathrm{C}$ or lower will generally require the use of a binary cycle. A binary cycle plant is similar in construction to a direct-use-plant but the main difference is in the medium that goes through the turbine. Because steam that is lower than $200^{\circ} \mathrm{C}$ should not be sent through the turbine, a substance that vaporizes at much lower temperatures should be used as the medium through the turbine. The low temperature steam is sent through a heat exchanger in which the other substance, usually iso-butane, is on the other side of the heat exchanger and then this substance is sent through the turbine. The provided map shows some geothermal sources, in the form of surfacing water, in Alaska. The map reveals that the most productive sources for good quality steam at higher temperatures are on the Alaska Peninsula in the close proximity of volcanic activity. The closest source, over $200^{\circ} \mathrm{C}$, to Alaska's largest city is across Cook Inlet from Anchorage and is well over 100 miles away. This is an obvious inconvenience since electric lines would need to be routed such a long distance and around such an obstacle as Cook Inlet. Most of the geothermal springs in Alaska are under $200^{\circ} \mathrm{C}$ and currently are being used to heat homes locally, for recreation at resorts, or are not being tapped. Low ground temperatures near the surface and permafrost limits the use of heat pumps. Because geothermal energy is associated with low emittance of $\mathrm{SO}_{2}, \mathrm{CO}_{2}$ and other pollutants and because there are many geothermal sources in the state, there is potential. 
Information provided by the International Geothermal Association, last updated in 1999, indicates that there was a plan to build a $15 \mathrm{MW}_{\mathrm{e}}$ plant at Unalaska, Alaska. With a population of over 4,300 and containing one of the United States' most productive fishing ports, Unalaska would be a great place to test geothermal electric generation in Alaska. Electricity currently costs $\$ 0.24 / \mathrm{kWh}$ in Unalaska. State subsidized power cost equalization benefits provided for many remote villages in Alaska, including Unalaska, help to reduce electrical costs there because the cost of producing energy is so high. The current mode of electric generation at Unalaska is via diesel generators. One of the main obstacles to implementing a geothermal plant there is the difficult terrain that separates the source and the city. This would increase capital costs.

\section{$\underline{\text { A third section follows }}$}

\section{Environmental Impacts of Energy Use}

The way we produce and consume heat and electricity can have profound effects on our environment. Such impacts can range from immediate consequences such as fuel oil spills or emission of carbon monoxide [CO] from motor vehicles to longer term issues such as safe disposal of radioactive wastes from nuclear power plants. In addition to the above direct impacts, there are also indirect or external consequences. These can include National security costs associated with safeguarding our infrastructure including power plants or rising sea levels due to global warming associated with greenhouse gases such as $\mathrm{CO}_{2}$ (http://www.aip.org/pt/vol-53/iss-11/p29.html).

As an example of a contentious national and global issue, the US DOE spent 14 years and $\$ 4.5$ billion on studies before recommending in January of 2002 that Yucca Mountain, a barren volcanic structure about $150 \mathrm{~km}$ [90 miles] from Las Vegas, be used to bury thousands of tons of highly radioactive nuclear waste from power plants and nuclear weapons factories. The project faces substantial technical, legal and political challenges, and could be derailed by either house of Congress, the courts or engineering problems. Nevada officials and environmental groups have questioned the ability of engineers to reliably predict that it will not leak significantly for 10,000 years, as government rules require.

Those in favor of this recommendation cite the 103 operating power reactors in the US that are running out of storage space or spending money to extend their storage capacity plus the danger from terrorist attacks. Most of the spent fuel is stored in giant steel-lined pools, which were intended to hold only a few years of their reactors' outputs, but now have decades of fuel. They are built to withstand earthquake, tornado and other threats, but could overheat and spread large quantities of radiation if drained in a terrorist attack.

On the other hand, some opponents say that the waste would be even more at risk on trucks and trains en route to Nevada. The mayor of Las Vegas, Oscar B. Goodman, said he would oppose the use of Yucca by rallying the mayors of cities along the transportation routes. He said that there were 109 cities with populations of at least 
100,000 on those routes, and 52 million people living within $0.8 \mathrm{~km}$ [half a mile] of the routes.

The federal effort to find a place to put wastes began in the 1960's. In 1982, Congress promised to have a repository open by January 1998, and the Energy Department signed contracts with the reactor owners to take their wastes, beginning at that time, in exchange for a payment of a tenth of a cent per kilowatt hour generated by nuclear power plants. Since then the government has collected about $\$ 17$ billion (http://www.nytimes.com/2002/01/11/national/11NUKE.html).

In the US, ambient air quality is guided by the National Ambient Air Quality Standards [NAAQS] which are part of the Clean Air Act last amended in 1990. This sets guidelines on allowable levels of $\mathrm{CO}, \mathrm{SO}_{2}, \mathrm{NO}_{\mathrm{x}}, \mathrm{PM}_{10}, \mathrm{~Pb}$, and $\mathrm{O}_{3}$. Electric power plants are major emitters of $\mathrm{SO}_{2}$ and $\mathrm{NO}_{\mathrm{x}}$, with combustion processes having emitted $27 \mathrm{M}$ tons in the US in 1997. These compounds are the precursors to acid rain and have adverse health impacts on humans and animals mainly by impacting respiration. Motor vehicles are the major source of carbon monoxide [CO] having emitted $67 \mathrm{M}$ tons in 1997. [deNevers, 1999]. Ozone is a pollutant at sea level and is formed from hydrocarbons and $\mathrm{NO}_{\mathrm{x}}$ catalyzed by sunlight. On the other hand, ozone is necessary in the stratosphere to filter our harmful UV rays.

Much attention has been devoted worldwide to climate change issues. The Third Assessment Report of Working Group I of the Intergovernmental Panel on Climate Change was prepared and reviewed by hundreds of scientists worldwide. It concludes that the global average surface temperature has increased by $0.6 \pm 0.2{ }^{\circ} \mathrm{C}$ over the $20^{\text {th }}$ century and that it is very likely the 1990 s was the warmest decade since 1861 . It also concluded that is was very likely the temperature increase in the Northern hemisphere was the largest of any century of the past 1000 years. Most of the warming over the past 50 years is likely to be caused by increases in greenhouse gas concentrations. Greenhouse gases such as $\mathrm{CO}_{2}$ and $\mathrm{CH}_{4}$ help trap the longer wavelength infrared radiation that is emitted from the earth's surface.

Suggestions for reducing emissions of greenhouse gases include: improved efficiencies of end use and energy conversion devices, shifting to lower carbon and renewable biomass fuels, zero emissions technologies, improved energy management, and reduction of process gas emissions (http://www.ipcc.ch/).

In Alaska, the major ambient air quality issue associated with our use of fossil fuel resources is excessive levels of ambient $\mathrm{CO}$ in urban areas during the winter. This places Anchorage and Fairbanks in jeopardy of being sanctioned by the US EPA. Indoors, Alaska has the highest age adjusted death rate from accidental $\mathrm{CO}$ poising in the nation with almost $10 \%$ of the homes in 5 villages studied having elevated levels (Howell et al, 1997). The most common cause was improperly ventilated hot water heaters.

A current issue in rural Alaska [and elsewhere] is the potential for ground water contamination resulting from bulk fuel oil storage. This has resulted in a major effort 
funded by the Denali Commission to upgrade bulk fuel storage facilities. Besides leading to occasionally ambient air $\mathrm{CO}$ violations, transportation can also be associated with ground water contamination resulting from fuel spills of diesel fuel and gasoline at service stations.

Even renewable-based technologies can have adverse impacts such as noise and bird kills from wind turbines and fish migration issues associated with hydropower. This leads to the saying "there is no free lunch". In deciding which technology to adopt, one must balance the pluses and minuses and look at total life cycle costs including environmental impacts.

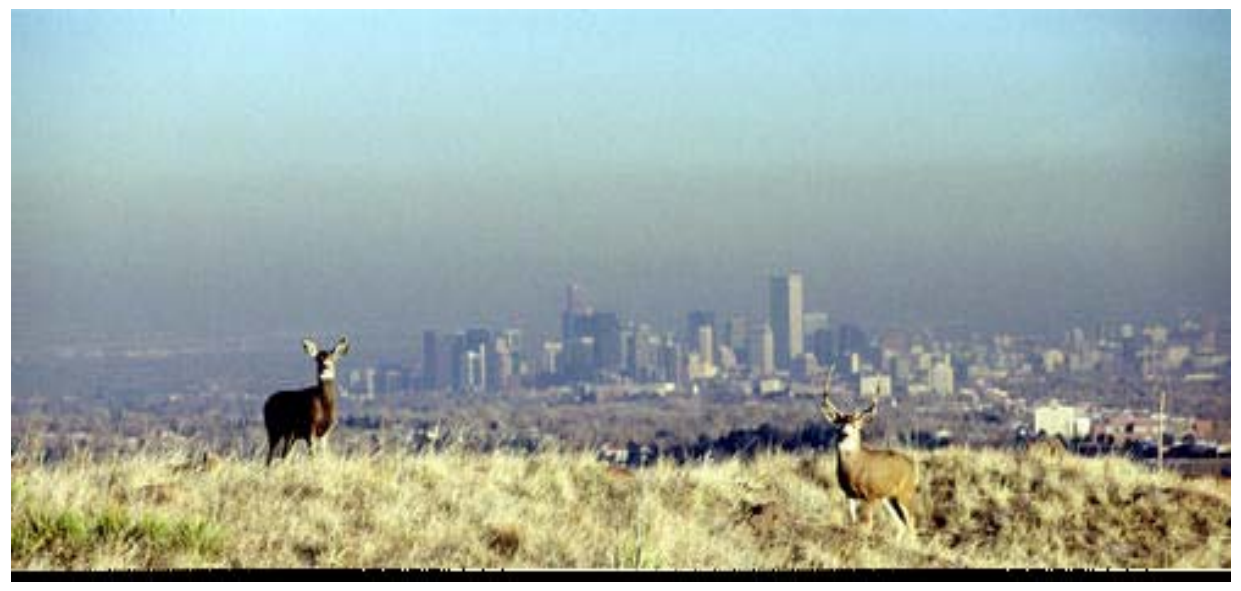

Denver Temperature Inversion. Photo courtesy of NREL.

\section{References:}

deNevers, N., 2000, Air Pollution Control Engineering, McGraw-Hill, NYC Howell, J., M. Kieffer, and L. Berger, 1997, Carbon monoxide hazards in rural Alaskan homes, Alaska Medicine, 39, pp. 8-11.

As this project ended over a year ago, the web pages have not been updated.

\section{CONCLUSION:}

The Energy Information Clearinghouse is useful as one site that integrates a wide variety of information relating to energy issues both world-wide and within Alaska. The information is presented in such a way as to be intelligible to the general public as well as to provide details with links to relevant www sites for those with technical backgrounds. 


\section{REFERENCES*}

These include

http://www.nrel.gov/lab/pao/biomass_energy.html

http://www.biomass.org/fact sheet 2.htm

http://www.eren.doe.gov/biopower/basics/index.htm

(Ristinen, R. and J. Kraushaar, 1999, Energy and the Environment, John Wiley and Sons, NYC)

http://www.sustainable.doe.gov/municipal/intro.shtml

http://bcn.boulder.co.us/environment/becc/

http://www.uaf.edu/coop-ext/publications/eehpubs.html

http://www.absn.com/index.html

http://www.eren.doe.gov/geothermal/geobasics.html

http://www.iclei.org/efacts/geotherm.htm

http://solstice.crest.org/renewables/geothermal/grc/supply.html

http://www.energy.ca.gov/geothermal/

http://www.nrel.gov/documents/geothermal energy.html

http://capp.water.usgs.gov/gwa/ch n/N-AKtext4.html

http://www.bchydro.com/business/etools/guides/EA-21.html

http://www.aceee.org/pubs/a984.htm

http://www.thermopride.com/thermo pride_oil_furnaces.htm

*A complete list of the citations may be found on the www site. 